Received September 7, 2016

Revised November 10, 2016

Accepted December 2, 2016

\title{
Xi Jinping's Leadership Style: Master or Servant?
}

\author{
KERRY BROWN*
}

Much commentary has been made about the amount of power that Xi Jinping has accrued since the leadership transition over 2012 and into 2013. He is interpreted by many as being the most powerful of modern Chinese leaders. But his leadership needs to be interpreted carefully within the organisation that he leads and whose interests he and his colleagues serve-the Communist Party of China. Looking at his relationship with this body reveals a more complex framework within which to see his real authority, one which implies that he is as much a servant of its corporate interests as he is an autonomous, selfserving agent.

Keywords: Xi Jinping, China, Leadership, Power, Politics, Authority

* Professor, King's College, London, the UK;

E-mail: kerry.brown01@googlemail.com

DOI: 10.16934/isr.17.2.201612.143 


\section{INTRODUCTION}

From November 2012, when Xi Jinping emerged as the Party Secretary of the Communist Party of China (CPC), he has been talked of as being the most powerful leader the country has had since the era of Deng Xiaoping, who was the paramount leader from 1978 to the 1990s. Some have even claimed his power equals that of regime founder Mao Zedong (Nathan 2016). But it is clear in these discussions that we need to differentiate between two levels of power, or two contexts within which to consider $\mathrm{Xi}$, to make any headway with this question. Once we differentiate between these levels we uncover a great deal of ambiguity.

On one level, Xi certainly has visible signs of power and authority. He accrued an impressive list of formal titles, spread across the main terrain of power in the PRC. As well as the key position of Party Secretary, he is also the President of the country, the Chair of the Central Military Commission in charge of all military matters, and heads several small groups, where Party and government entities meet to decide core areas of policy. Amongst the most significant of these are the Small Leading Group on Comprehensively Deepening Reform, which was established after the Third Plenum of the CPC in October 2013, and which gives feedback and direction on the overall progress of reform in China, and the Small Leading Group on Foreign Affairs. Sitting at the heart of a reduced Standing Committee of the Politburo (from nine members between 2007 to 2012 down to seven now), $\mathrm{Xi}$ seems to be truly, as one description has it, the Chairman of Everything (Miller 2008; Perlez 2015).

However, there is another narrative and context where $\mathrm{Xi}$ can be placed-and that is the faithful servant and representative of the Party, someone who has been put in a position of exposure and vulnerability, because of the CPC's decision to streamline and focus leadership functions to give greater clarity and accountability about where decisions are being made and who has responsibility for them, and more powers of enforcement to ensure that once decisions are reached they are actually implemented. In this context, as the country goes through a series of unique challenges, trying to reconfigure its economy, dealing with falling GDP growth, wrestling with massive sustainability issues and keeping the middle class happy, there is a sense within the CPC of a constellation of unique challenges that it must be able to manage if it is to survive. Having a leadership that looks centralised and speaks with a single voice is tactically useful in this context.

If the reality is closer to the first than the second interpretive framework, then $\mathrm{Xi}$ will shape up to be a modern autocrat, someone building a personal power base for their own interests. That would be a worry both to the CPC and to the wider world. If it is the second framework, then there is a more benign political logic to, for instance, some of the campaigns that $\mathrm{Xi}$ and the leadership around him have spearheaded over the years since 2012, and in particular the anti-corruption 
campaign. These are for the preservation of the Party's collective interests, not the individual ones of Xi. His style of leadership is a means to an end-the achievement of sustainable one party rule in China. Do we have evidence to help us come down on one side or the other of this divide?

\section{THE HU ERA: THE LOST YEARS?}

Some context might be useful in trying to determine which framework above is most accurate. The Canadian Chinese novelist Chan Koonchung had captured something of the spirit of the 2000s in his celebrated novel, 'The Fat Years', published in 2011. The vision of China in this work was of a place overwhelmed by self-satisfaction, in which wealth has become so unbridled that people were literally, in Chan's words, expiring with self-satisfaction. But beyond its exuberant satire, the moral message of the work was also clear: Chinese society had become so engorged with money, material gain and surface prosperity that it had lost its soul. Chan's diagnosis was to prove eerily correct in one respect. Over 2011 and into 2012 a series of events proved that some members of the political and business super elite in China had lost their way (Chan 2011). Politburo member and Party Secretary of Chongqing, Bo Xilai, son of a former revolutionary leader and himself spoken of as one of the most promising, popular politicians of his generation, was embarrassed by his wife, Gu Kailai, being involved in the murder of a British businessman in late 2011. Bo was tried for corruption in 2012 and formally sentenced to life in prison a year later. That same year, a key advisor to $\mathrm{Hu}$ Jintao and his closest aide, Ling Jihua, was similarly stymied by his son being found dead in a car crash with two naked females, both reportedly ethnically Tibetan. It did not help that the car involved in this tragedy was an expensive Ferrari. Ling was expelled from the Party and sentenced to life in prison in 2016.

China in the era of Hu Jintao seemed to be a place where GDP growth was growing from everywhere, but where the Party was in danger of simply becoming a wealth creation entity and nothing else (Brown 2014). From entry to the World Trade Organisation (WTO) in 2001 to 2012, the economy quadrupled in size. This was despite the impact of the great financial crisis of 2008-9. Fiscal stimulus by the government pumped vast sums of money from 2009 into the Chinese economy. State and non-state companies poured out profits. Communist Party officials were increasingly drawn into a web where they were passively colluding, and often actively collaborating, with the siphoning off of vast amounts of wealth that by rights should have been returned to the central state or its agents. As Andrew Wedemen, an American political scientist who studies corruption, made clear, the simple fact was that the Communist Party of China was engaged in a massive paradox: corruption was universally believed to be inimical to strong, sustainable growth, and yet in China in the decade after 2001 it seemed to happily sit beside 
such growth (2012). In the acid words of one official interviewed by Ben Hillman $(2014,115)$ during this period, 'If you're not corrupt, no one will trust you.'

That the CPC was undergoing a kind of crisis in its mission and moral standing was clear. Evidence from the Internet showed officials being exposed for arrogance, corruption, and brutality almost daily. One official who was denied the right to board a plane ended up trashing the boarding gate area. Another sat complaining loudly about how Chinese people (the 'lao baixin' of popular discourse) were lazy and small minded while feasting on expensive delicacies. These, and many other vivid displays of official arrogance, went viral in China, spread by the 900 million users of social media.

Politically, however, the Hu era had seen the failure of a nine-strong standing committee, where the extension of those making decisions had led not to greater activity but to policy paralysis. The philosophy under Hu of low key, collective leadership had led in practice to failures to make decisions in key areas from reform of the one child policy, of household registration, and of issues like China's position on the environment. There were clear divisions between Premier at the time Wen Jiabao and his colleagues over the pace and role of political reform, which became increasingly public from 2009. In that year, marking the $30^{\text {th }}$ anniversary of the Shenzhen special economic zone, Wen had stated that 'without the guarantee of the reform of the political structure, the achievements made in the reform of the economic structure will be lost and it will be impossible to realize the goal of modernization. It is necessary to protect the people's democratic rights and interests and their legitimate rights and interests'. He went on:

Excessive concentration of unrestrained power, create conditions for the people to criticize and supervise the government and resolutely punish corruption; it is necessary to build a society with fairness and justice, and it is especially necessary to ensure judicial justice, pay attention to protecting and helping the easily vulnerable groups, and enable the people to live with a sense of security and to have confidence in the development of the country (Wen 2010).

This was at the same time as his colleague Wu Bangguo was insisting that the state-owned sector of the economy was the most important, and that China should set its face against any attempts to adopt western models of democracy and multiparty politics (BBC 2009).

Even more toxic was the inability of the Hu leadership to deal with fundamental issues of state security. In April and May 2008 Tibet erupted in protests. In July 2009, Xinjiang witnessed riots in its capital Urumqi where over 200 died. Inner Mongolia similarly experienced protests over the death of a Mongolian herdsman in 2011. Data collected by the Chinese Academy of Social Sciences showed that in the era of 'harmonious society' heralded only a few years earlier, 
there were close to 100 thousand mass incidents that had to be dealt with by public security agents annually (Wang 2009). Chinese society seemed as it was becoming wealthier to be overwhelmed by divisions, some of which had seeped into the very heart of the CPC itself. It was a body becoming undisciplined, inefficient, and ill directed. In that sense, the Xi Jinping style of leadership operates as a remedial response-a corrective to the Party's loss of its way in the era of super high growth, but low political direction.

\section{THE CASE FOR XI THE AUTOCRAT}

There is evidence broadly supportive of the idea that Xi has attributes and characteristics that make him look autocratic. Firstly, there is the issue of how quickly and completely his elevation in November 2012 happened. The transfers of power to him through the full trilogy of positions (head of military, president and head of CPC) happened over a six-month period, faster than any previous generational transition. Jiang Zemin's succession occurred in a series of incremental steps from his surprise appointment as Party Secretary after the fall of his predecessor Zhao Ziyang during the Tiananmen Square uprising in June 1989. Hu Jintao's accrual of the main three slots occurred over a two-year period from 2002 to 2004. A mere six months to be Party, country and military head is therefore unprecedented. It is particularly striking too that $\mathrm{Xi}$ has been accorded a new title, 'Commander in Chief' as of April 2016, and has been given the title 'core of the fifth generation leadership' at least by some provincial leaders and Party figures (Rajan 2016). This title had always been denied to Hu Jintao, and was interpreted by some as his failure to ever receive recognised status within the full Party elite.

Secondly, there is the issue of visibility. In state media, Xi Jinping often heads almost every story. Dense coverage of his work, his travels abroad and his speeches has been compounded by the publication, very early in his period in power, of a book of his speeches, 'The Governance of China', issued in several languages in 2014. For Hu Jintao, no such collection ever appeared any time in his decade in power, and for Jiang Zemin only towards the end of his tenure. $\mathrm{Xi}$ himself has used blogs, and has his own social media presence, as well as being placed centrally in all the major state media coverage. This has been compounded by Xi's visit to the Chinese Central Television station in February 2016 where he demanded that journalists remained 'truthful to facts', with increasingly strident stipulations about how they can and cannot cover news items and speak about Chinese leaders.

Thirdly, to revert to the issue about Xi's leadership of seven of the twenty plus Leading Small Groups referred to above, Xi has placed his name across almost every area of domestic and external policy. This ranges far beyond the visibility of his chairmanship of leading groups and occupation of formal Party 
and military positions. In the Third Plenum, in his own name he issued an 'Explanatory Note' accompanying the Plenum Communiqué. Because the Plenum had addressed in detail the issue of economic reform, this would naturally be an area where the main person ostensibly in the lead on this Li Keqiang, might have a voice. Even more remarkable was the fact that the Communique itself with its 60 commitments was already a lengthy document. Why the need for extra explanation? The personal statement almost came across as an assertion by Xi that his was a comprehensive, not a partial leadership, and that there was no area where he would not stamp his mark.

Fourthly, the anti-corruption struggle which started in earnest from 2013 has lapped at the doors of some individuals who might be construed as potential political opponents or enemies. Bi Xilai, referred to above, has been seen in some places as a figure who was directly competing with $\mathrm{Xi}$ in the contestation before the 2012 succession, and whom the issue of corruption offered an excellent excuse for marginalisation. Ling Jihua, also referred to above, was so close to Hu Jintao that his own political demise was hard not to interpret as a repudiation and distancing from the 2002-2012 era. There have been plenty of other figures in the military, the state-owned enterprise system, state security and the ideological apparatus who have also been removed for reasons that look, on the surface, to be highly political. For some, a full blown clear up of corrupt officials in China would equate to taking in everyone. It is hard therefore not to conclude that the choice of final targets is made according to political criterion, and it is the potential, or actual, opponents of $\mathrm{Xi}$ who have suffered the harshest treatment.

\section{AUTOCRAT: THE CASE AGAINST}

Each of these four points could be seen as signs of Xi's construction of a personal power base-but they also can be seen as motivated by political necessities which are in the interests of the Party, not an individual. For the first, quick succession delivered stability and predictability when there may have been dissent and confusion for the CPC. Nor have there been a huge number of successions before to give precise rules on how to conduct this. Jiang Zemin came to power in the highly unusual circumstances of the 1989 uprising. It is not surprising therefore that his position took several years to stabilise and make secure. This means that the first partially regulated succession happened over 2002 into 2004. Surely, there is an argument to say that 2012 was therefore a refinement in terms of speed and decisiveness of what had happened before. That it happened so quickly and completely is simply a sign of the Party's maturation of its elite succession process, not evidence of a grab for power. It was an intentional thing, and something most elite CPC leaders supported because they knew a messy, indecisive and contested process would be problematic and potentially highly damaging to their collective 
interests.

For the media and policy ubiquity too (second and third reasons above), these can be interpreted just as easily as the presentation of $\mathrm{Xi}$ as the face of a leadership in which the messages, and the ways in which messages and policies are being promoted, is more unified. They are an attempted antidote to the scrappier, confusing and ineffective approach of the Hu years in which the CPC had shown too much internal dissent, in which the media and the policy approach had been too disjointed, indecisive and sometimes simply self-defeating. Xi there-fore is strategically placed as the front man, to show that this unity is now back in place, and to be the 'face' of the CPC. For policy issues, too, implementation and detailed formulation of policy still remain in the hands of the Premier, the State Council, and the ministries, down to the provinces. It is therefore just in terms of presentation that $\mathrm{Xi}$ is placed centre stage. His leadership visibility in these areas has functional reasons, and is not indicative of real substantive influence. Indeed, in a country as complex to govern as China now is, it would be hard to understand how any single figure could do more than simply symbolically place themselves at the heart of everything, rather than pretend that they might get involved in the daily detail of policy making.

Finally, to counter the idea that the anti-corruption struggle is a power purge serving Xi's own networks and vested interests, it can also be easily interpreted as a campaign to enforce discipline and a necessary cleaning up of an entity that had confused its commercial and economic aims in the previous decade with its political ones-for which one can refer to the passage on the venality and out-of-control official greed and malfeasance of the Hu years above. Even looking at the targets that have been brought down in the campaign across the various areas of the government, state owned enterprises, finance and military, there are no easy narratives to draw from those who have been removed. Some were not opponents of $\mathrm{Xi}$, others were perhaps even people once seen as close to him. A figure like Zhou Yongkang himself, formerly a member of the Standing Committee of the Politburo, was already retired when finally tried and sentenced for corruption. $\mathrm{He}$ personally would have offered no direct competition to Xi. And the precedent of trying him (showing that even members of the Standing Committee could be held accountable and formally tried for corruption after they had retired, something that had never happened before in the PRC history) was one that could rebound of Xi and any of his other colleagues once they too eventually retired. Why do something that might one day work against you, creating a precedent that might eventually become a trap? In this context, $\mathrm{Xi}$ was either remarkably arrogant, or simply doing what had been collectively agreed in the Party was strategically for its best interests - governing itself better, making sure its members did not become a major problem, and trying to instill discipline in a challenging era where unity was important above all else. 


\section{NO MAO}

Before being seduced too much by the 'Xi the autocrat' idea, there are some other counterbalancing ideas above and beyond the ones given previously. They work to this idea of how leaders in the CPC now see themselves as situated within a highly established, organic and comprehensive network of CPC power, and how much they insert their personal interests into the interests of the CPC itself. Xi and his colleagues come from the Cultural Revolution era, which ran from 1966 to 1976, when Mao Zedong died. They have firsthand experience of what autocratic, charismatic, personalised power looks like, because it reached its apogee over this period. The personal costs and impact of this era and style of politics were very high for some of them. Xi's own father, Xi Zhongxun, spent almost two decades either under house arrest, or in prison, after 1962. Since 1978 and the Dengist era, the predominant idea has been to institutionalise the leadership of the Party so that it never again falls to the whims of 'rule of man.' Set terms have been informally introduced, for instance, where leaders are expected to retire from formal positions of power after the age of 68 . There is more circumscription around the powers of specific leaders. As time goes on, the trend has been to stress collective responsibility, not focus on one person.

On the surface, because to the way Xi speaks and appears, this trend seems to have been reversed. But a reversion to Maoist era personality cult politics would be a major step backwards, and undermine, potentially even destroy, so much of what the Party has done to insure itself against being hijacked by the agendas of one person and a clique around them. These reforms emerged after 1978 because of the trauma of Maoism. If Xi is becoming an autocrat, then this would be an admission that the experiment since 1978 to institutionalise leadership and make it more predictable and sustainable has failed. It would be potentially a return to the addiction to one-person led rule. It would also be truly remarkable that Xi had been able to effect this reversal so quickly and with such a lack of internal opposition. There would have been at least some signs of clear divisions and dissent amongst the elite because of the epochal nature of what was being attempted. So far, such evidence of serious internal opposition has been lacking, implying that in the CPC elite at least, Xi does not look quite like the autocrat he appears in the outside world, but something different. There is a more complex story unfolding here.

More than this, while $\mathrm{Xi}$ is spoken of as Maoist leader in his style, language and use of propaganda, the China which existed under Mao Zedong and that which exists today are like different planets. We are therefore not comparing like with like. Take the example of Xi talking to the People's Liberation Army (PLA), and designating himself Commander in Chief. The PLA as an institution is radically different to that which existed up to 1978 . The sole continuity between 
these two eras is that the PLA was, and remains, the servant of the Party. But it now functions as a highly specialised and focused military entity. Its commercial interests have diminished since 1998. No generals sit on the Standing Committee, and only two on the full Politburo. The PLA has remained wholly loyal, and in return been given large budget settlements, more professionalisation, and a greater role in a smaller, more central number of issues like Taiwan and regional security. Xi's stress on political control for the PLA looks like a further extension of his powers. But it could just as well be an attempt to ensure that the PLA does not creep more into money making, political areas, and that it confines itself to its legitimate security and military issues. Surely for the outside world, this clarity (politics in the Party, fighting and implementation of defence policy in the PLA) is a good thing. It reduces the likelihood that the PLA will become an autonomous and disruptive political agent in its own right. More significantly, it does mark a development in Party rule, in its maturation and refinement. The Party is setting out clearly the role of the PLA, the areas where it can speak, how it can speak, and what its locus is. That sort of clarification is a symptom of modernity, not regression to a Maoist era of autocratic politics where the Party was far less regularised and institutionalised than it is today and one person could, and in the person of Mao did, hold it to ransom and fundamentally dictate and challenge it (Saunders and Scobell 2015).

A final issue concerns ideas. Ideas are important for power. Those that win arguments tend to win influence. Ideas give power longevity and sustainability. Ideology in China is still important for precisely this reason. It helps to set agendas. This is why there are 2,500 Party schools training cadres in socialism with Chinese characteristics, and why the leaders still speak so much about ideological commonalities. Ideology shows consistency of purpose and world view, and demonstrates links with the Party's historic roots. China in 2016 still operates within the pragmatic framework introduced and made viable by Deng Xiaoping. This accepts the market as a tool for Party control through delivering economic growth, accepts foreign capital but under terms China designates and allows, and asserts a vision of China being a socialist nation but a rich and strong one.

$\mathrm{Xi}$ Jinping has introduced ideas like the 'Four Comprehensives,' and the China Dream, along with notions like the Belt Road Initiative' for foreign policy. But he has not fundamentally recast the intellectual terrain in China and announced a ground breaking new vision and framework for the country's future development. On the whole, with modifications, the Communiqué at the Third Plenum in 2013, the legal changes announced broadly in 2014 at the Plenum that year and everything since, has operated in the reformist mould fathered and sponsored by Deng and his colleagues three decades earlier. Maoism with its emphasis on class struggle and assertion of Utopian aims, is dead and buried. China today is still operating not on $\mathrm{Xi}$-ist principles (no one can really explain what they might be) 
but Dengist ones. The one area where Xi might be able to announce bold new ideas, the political realm, is thus far also the one where he has shown himself to be most conservative and unlikely, unless forced, to act.

This issue of ideas is also important when considering networks and people around Xi. In what ways could it be said that he has allies, if there are no strong, distinctive ideas that he can claim as his own and which others can rally around and follow? Deng's great achievement, as Alexander Pantsov and Stephen Levine have argued in their recent study of him, was that socialism in China became viable in its embrace of certain market principles and in its maintenance of a strong, guiding hand for the Party (Pantsov and Levine 2015). The boldest ideological move, made between 2012 and 2016 under Xi, was simply to accept that the market was necessary, rather than preferential, for reform, which happened in 2013. This single idea however is still largely one that exists in the realm of rhetoric rather than reality. In the Shanghai Stock Exchange falls of July 2015 and January 2016, the Party leadership mandated state intervention to prop up falling values, running against their commitment from two years before. Because there is not a coherent body of ideas which can be labeled easily as Xi-ism, then it is very hard to say what someone is if they are labeled a ' $\mathrm{Xi}$ ' supporter? For this reason, so far it has proved very hard to say precisely who Xi's allies in the political system are. He does not have an easily identifiable patronage network. The most that can be said of him is that he has employed people close to him who he had worked with before. This is hardly autocratic mania, but a distinctive feature of leaders across the world.

The lack of any easy meaning to the idea of a 'Xi clique' or a 'Xi band' has led some to talk about a Fujian band, because of Xi's lengthy period working in this south eastern coastal province from the 1980s into the early 2000s (South China Morning Post 2015). But at most this shows bureaucratic preference, not some cohesive group of people married to Xi's personal power vision and goals, or feeling like they have a vested interest in supporting him against all other leaders. Asserting a 'Xi' clique shares the same problems as most talk of factionalism in contemporary China-it grants a level of cohesion to networks which they probably do not have. As in any fast changing political context, inside and outside China, alliances form, change, develop or decline, and are highly dynamic. The notion of there being some neat ' $\mathrm{Xi}$ ' faction therefore has proved very difficult to pin down (Brown 2015, 160-172).

\section{SOLVING THE ISSUE OF XI'S POWER: HIS RELATIONSHIP TO THE CCP}

One of the most obvious and necessary starting points for understanding Xi's real powers relates to his relationship with the organisation that he leads, which he 
has worked in across his professional life, and which he had belonged to since 1972-the Communist Party of China. Xi makes sense as a Party leader and member. Seeing his power as separate from this entity is like trying to see two parts of a compound chemical in isolation. Xi would not be where he is, doing what he is doing, without the CPC. Here he is very different to Mao, who joined the CPC when it was a tiny minority group, and who built up a level of power and influence which often seemed to make the CPC his own servant rather than the other way around. For $\mathrm{Xi}$, this sort of development would be unimaginable. He is a Party leader and his powers are inseparable from the CPC. In that context, and that context alone, he should be understood.

The core question therefore is not so much who is $\mathrm{Xi}$, but what is the Party that he leads and what functions does it have? Answering those questions means formulating a clearer idea on how Xi's leadership helps deliver those goals. The prime function of the CPC in the $21^{\text {st }}$ century is to be a tactical, strategic body-to decide on the parameters and priorities for action as China moves towards its objective of being a strong, great nation once more. Xi himself has talked of two centennial goals-achievement of middle income country status in 2021 when the CPC celebrates a hundred years in existence, and then the delivery of democracy with Chinese characteristics in 2049. Each of these objectives has appeared before his own ascendancy, albeit with slightly different labels. Hi Jintao talked also of a 'historic mission' in the mid-2000s which included roughly the same terrain. $\mathrm{He}$ also asserted the need to achieve a 'moderately prosperous society' by 2021, the 'xiaokang shehui' (小康社会) which appeared in his speeches delivered around the time of the $17^{\text {th }}$ Party Congress in 2007 (the one that marked the rise of Xi). Jiang Zemin before him opined on the two decades of 'strategic opportunity' to 2021 when the country would be able to develop its domestic economy while enjoying a relatively benign international environment. Predating these were the '24 character' ideas credited to Deng-of China 'keeping a low profile, building its capacity, and making itself strong'. It was also Deng who suggested the 2049 date for the perfecting of Chinese modernity and democracy, a natural enough point to focus on because of its marking the centenary of the PRC. Setting out goals is not something unique to $\mathrm{Xi}$. It is, rather, a mark of how much he fits into the template of previous leadership.

There is another, more profound place where $\mathrm{Xi}$ shares the mindset of elite Party leaders in the CPC history, and is striking for being so similar, rather than dissimilar, to them. The CPC has always held a view imputing almost scientific progress and direction to history. Here the $\mathrm{CPC}$ is the same as sister Marxist parties elsewhere in the world, both in the past, and the ones that still exist to this day. Its leaders believe in variant forms of dialectic materialism. For them, therefore, history is made up of forces which humans simply serve and fulfill, moving by thesis and antithesis towards scientific development and incremental perfecti- 
bility. In this larger context therefore, $\mathrm{Xi}$ and his leadership understand themselves as occupying a space in this narrative of historic development, just as their predecessors did. In some ways, it is almost anti-person, and ascribes most influence and importance to collective desires and wishes and the impersonal, immutable laws of history and historic development. The Party therefore, and its sustainability and longevity, lie at the heart of this march towards the future. Leaders serve the CPC mission, not the other way around.

Within this CPC context, Xi's function is to achieve two things. One has been referred to above, and relates to the sense of the threat to the Party's moral mandate to rule. It is to rescue the Party, the entity that his father served for his entire life, and which Xi himself has worked for all his professional career, from the associated collapse of public authority because of the Hu years. These challenges that the CPC's money making prowess led to were referred to above. $\mathrm{Xi}$ had referred to this alienation between the CPC and those it was meant to be serving in the first comments he made as Party Secretary in November $15^{\text {th }} 2013$ : 'In the new situation, our party faces many severe challenges', he stated,

and there are many pressing problems within the party that need to be resolved, especially problems such as corruption and bribe-taking by some party members and cadres, being out of touch with the people, placing undue emphasis on formality and bureaucracy must be addressed with great effort.

He went on:

Our responsibility is to work with all comrades in the party to be resolute in ensuring that the party supervises its own conduct; enforces strict discipline; effectively deals with the prominent issues within the party; earnestly improves the party's work style and maintains close ties with the people. So that our party will always be the firm leadership core for advancing the cause of socialism with Chinese characteristics (Xi 2012)

In this formulation, made on the first day in which he appeared as Party leader, it was the CPC's interests, its restoration of a moral mandate, and legitimacy after a decade in which this had been eroded, that were most stressed. In many ways, therefore, it is remarkable that $\mathrm{Xi}$ has remained so close to the first words he said. Much of what has happened over the ensuing years to mid-2016 can be seen simply as moving to implement what these statements had prefigured.

Perhaps this is because Xi had been consistent prior to this in holding a purist vision of the realm of politics in Chinese life. Wealth creation evidently figures in his world as a political tool, but not an end in and of itself. With the falling away of GDP growth, and the decline of profitability for the state-owned enterprises, the 
venality of party officials from the decade before became much more exposed and problematic. The material benefits were no longer there for them to feast on. Suddenly, the Party's principle source of legitimacy since 1978, economic growth, was under threat. New sources needed to be found. One of these was to ensure that the Party's years of rich living and excess ended quickly. The anti-corruption campaign therefore was aimed at Party members themselves, enforcing fear and discipline in them and causing them to return to their political functions, and not to continue with their commercial interests.

As paramount leader, $\mathrm{Xi}$ sits at the heart of this tactic of restoring the Party to its central part in the life and development of China. The argument he presents is that whatever public views of the $\mathrm{CPC}$ might be, there is recognition that it remains the best bet for assisting China in achieving, for the first time in modern history, its moment of rectification, when it becomes a great, rich and powerful nation, one with internationally respected and recognised status, able to fulfill its mission of autonomy. If there is a new development under $\mathrm{Xi}$, it is the increase in nationalist focus by him and his colleagues. Frequent travel abroad (forty countries between March 2013 and September 2016) by Xi reinforces this message, domestically, that China is now a truly global power.

$\mathrm{Xi}$ has also been in the lead in improving the messaging capacity of the leadership. In the $\mathrm{Hu}$ era, domestically and externally, China was seen to be speaking either too quietly, or simply not occupying the sort of prominent space that was its right. $\mathrm{Hu}$ Jintao was reticent, low profile and shy. $\mathrm{Xi}$ is as much about presentation as substance. It is not so much what he is saying that deserves attention-this is not radically different from previous leaders. What is important is the way he is saying it, with more clarity and more directness.

$\mathrm{Xi}$ does differ from his predecessors in some areas. One is simply that he is a better and more confident public speaker than $\mathrm{Hu}$ was. But he is also clearly a politician, rather than a technocratic administrator. He shows little interest in the minutiae of policy making, but he does show an ability to hone in on certain key messages which go down well with the public-from the popularity of the anticorruption struggle, to his appearance in the street, visiting a small eatery in 2014, and working amongst farmers in 2015.

\section{CONCLUSION-AND CAVEATS}

Despite its technocratic exterior, leadership in China has often been placed in frameworks where the temptation to present it as highly personalised and tied to the agendas of specific, very powerful individuals has high explanatory power. Leaders in the modern era are presented like suns in the middle of vast universes, with every part of the political firmament revolving around them.

Part of this is because of the continuing shadow of Mao Zedong, whose 
powers and influence were extensive. But this was in an era where Chinese society, governance and media were far less complex than today. In the $21^{\text {st }}$ century, a Chinese leader must be highly tactical about the spaces they wish to influence and control. One of the core skills of a politician in modern China is to know best the spaces to do this in, and the ones best left for people to plot their own paths.

Xi Jinping presents a leader who appears to be strong. But pulling apart image and reality is important, especially because the Communist Party he heads has proved so adept at concealing its internal rules. Looking at the external manifestations of Xi's power, through his way of speaking, his muscular foreign policy, and the drama of the anti-corruption struggle, should not distract us from the harder business of saying what precisely his power is attempting to achieve, how well it has done so far, and in what ways it is fundamentally redirecting Chinese society. These, after all, were the achievements of figures like Mao and Deng. China was a different place after their periods in power as a direct result of some of the decisions they made and the ideas they promoted. Can we imagine ever being able to say this about $\mathrm{Xi}$ ?

My argument in this essay has been a simple one: that so far (as of September 2016) Xi Jinping is more of a continuity leader, whose ambitions and actions have been to build on ideas and initiatives of previous leaders, rather than one who is initiating a new kind of approach and a new body of ideas. $\mathrm{Xi}$ is following the largely market-directed orthodoxy of every leader since 1980, and is intensifying the process of greater Chinese influence internationally that has been around since the 1990s. In some senses, to have a leader who was low profile and quiet, in an era when China is so evidently one of the world's most important economies, would be a true anomaly, rather than someone like Xi.

As a continuity leader, therefore, Xi's principle function is to continue the fundamental strategy running from Mao, through Deng, to Jiang and $\mathrm{Hu}$-to maintain one party rule. $\mathrm{Xi}$ has the fortune of also building on their work in making sure that it continues to exercise a monopoly on power. $\mathrm{Xi}$ is a powerful leader only in as far as the Communist Party is powerful. He does not have the resources of political and charismatic authority as Mao did that are independent from the CPC. He serves it. This means that language about him being an autocrat must also factor in the fundamentally autocratic nature of the Party. They are part of the same package, as it were, and making sense of Xi outside of this context is not sensible.

There is a major caveat in all of this however. We are only just over one third of the way through Xi's period when he is supposed to be in power. There are two possibilities that cannot be discounted, both of which would be very negative in their impact within China and in the wider world. The first is that the personal opportunities for aggrandisement and power go to Xi's head. So while he might not be an autocrat at the moment, and may have sincerely never intended to do so, 
the temptation to accrue more power would prove too great. He is, after all, only human. In this case, more of his supposed opponents might disappear, and the personality cult around him might intensify. It is hard to see how far this tactic might succeed in a society which is so complex and where the onus is on material results is so great. An autocratic $\mathrm{Xi}$, seduced by power, might therefore chose to embark on a second strand of risky behaviour, ratcheting up support for himself by intensifying his nationalist messages. The reception of these in the outside world would be very negative, creating the real possibility of a Putinesque style of politics in China, where Xi seeks support locally by trying to appear strong and assertive with the outside world.

It is important to think about Xi Jinping's power, its true nature and extent. This is because of the dangers attendant on overestimating what he can do. Today, there is a belief that he is the master of all he surveys in China, and can achieve pretty much anything. But that is a comforting chimera. China is entering a period of real challenge and crisis. It is not easy to see how it can build the new economic model with higher consumption, services and urbanisation, sustainably at least, at the speed on the scale it wishes to do this. Nor is it clear that a one-party state political structure will be able to last through this transition without fundamental political compromises. The tactic of having a more personalised, centralised leadership focused on $\mathrm{Xi}$ at least creates the illusion of command and control-but it might be no more than that, a simple illusion.

Chinese politics is now extremely complex, and developing in ways where it is hard to see the outcome. The expectation for $\mathrm{Xi}$ is very simple. He has been given the task of making one party rule sustainable, with the assumption that the best way to achieve this is to continue to deliver raised living standards to most people in the country, and to focus on their hopes that China will, this way, become a rich, powerful country. Mobilisation and enlistment of public support around these two deliverables is important. Failure to deliver on these tasks will mean that, autocrat or not, Xi's position will be extremely precarious in the coming years. We may well end up then looking back and seeing much of what has happened during this ambiguous era as signs of weakness, not of real strength.

\section{REFERENCES}

BBC. "China Will Not Have Democracy." in BBC news website, last modified March 9 2009, accessed May 16, http://news.bbc.co.uk/1/hi/world/asia-paci fic/7932091.stm

Brown, Kerry. 2014. Carnival China: China in the Era of Hu Jintao and Xi Jinping. London: Imperial College Press.

Brown, Kerry. 2015. "Factions in Modern Chinese Politics: A Help or a Hindrance," The Journal of the Oriental Society of Australia, 27, 60-72. 
Chan, Koonchung, 2011. The Fat Years. New York: Random House.

Hillman, Ben. 2014. Patronage and Power: Local State Networks and Party State Resilience in Rural China. Stanford: Stanford University Press.

Miller, Alice. 2008. "The CCP Central Committee's Leading Small Groups" In The China Leadership Monitor, No. 26, last modified September 2 2008, accessed September 5 2016, http://www.hoover.org/sites/default/files/uploa ds/documents/CLM26AM.pdf

Nathan, Andrew. 2016. "Who is Xi?" In The New York Review of Books, last modified May 12, 2016, accessed May 16'2016, http://www.nybooks.com/artic les/2016/05/12/who-is-xi/

Pantsov, Alexander V and Steven I. Levine. 2015. Deng Xiaoping: A Revolutionary Life. Oxford: Oxford University Press.

Perlez, Jane. 2015. "Q and A: Geremie R Barme on Understanding Xi Jinping." In The New York Times, last modified November 8 2015, accessed May 12 2016, http://sinosphere.blogs.nytimes.com/2015/11/08/china-xi-jinping-gere mie-barme-maoing-xijinping/? $\mathrm{r}=0$

Rajan, D. S. 2016. "China: Imminent Grant of 'Core' Leader Status to Xi Jinping?." In South Asia Analysis Group, last modified February 3rd 2016, accessed May 16 2016, http://www.southasiaanalysis.org/node/1941

Saunders, Philip C and Andrew Scobell. 2015. The PLA Influence on China's National Security Policymaking. Stanford: Stanford Security Studies.

South China Morning Post. 2015. "Chinese Leader Xi Jinping's Trusted Fujian Proteges are ones to Watch in Next Party Congress, say Analysts." In South China Morning Post, last modified September 16 2015, accessed March 16 2016, http://www.scmp.com/news/china/policiespolitics/article/1855647/xijinping-and-fujian-proteges-he-puts-his-trust

Wang, Weilan. 2009. "Making Sense of Mass Incidents." In Global Times, last modified May 30, 2009, accessed May 16 2016, http://www.globaltimes.cn/con tent/433271.shtml

Wedeman, Andrew. 2012. Double Paradox: Rapid Growth and Rising Corruption in China. Ithaca: Cornell University Press.

Wen, Jiabao. 2010. "Zhi you jianchi gaige kaifang guojia cai you guangming qiantu." [Only by upholding reform and opening up can the country have a glorious future] in Xinhua last modified. August 22, 2010, accessed May 16 2016, http://politics.people.com.cn/GB/1024/12505398.html

Xi, Jinping. 2012. "Full Text: China's New Party Chief Xi Jinping’s Speech." at BBC News Website, last modified November 15 2012, accessed May 16 2016, http://www.bbc.co.uk/news/world-asia-china-20338586 